\title{
Nursing Students' Coping for Burnout and Fatigue Online Learning during Coronavirus Disease 2019 Pandemic
}

\author{
Tri Nurhidayati*, Desy Ariyana Rahayu, Dera Alfiyanti \\ Department of Nursing, Faculty of Nursing and Health Sciences, Universitas Muhammadiyah Semarang, Semarang, Indonesia
}

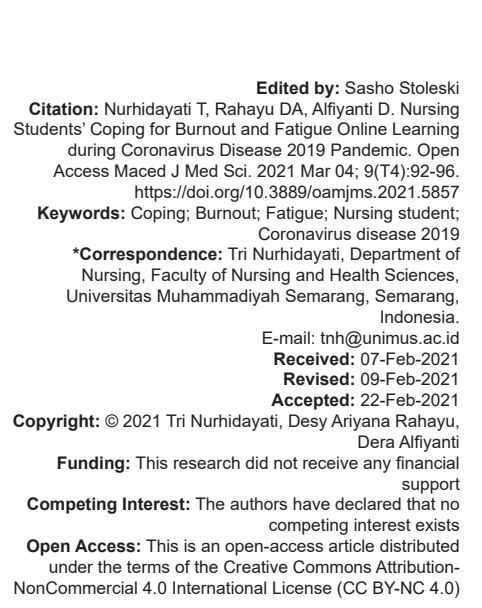

\section{Introduction}

The development of information technology is in line with globalization. As we know, globalization brings foreign culture to Indonesia, and we do not even realize that sometimes the information is a cultural tool for foreign countries. However, different from television, radio, and print media, which are regulated by the government, the internet is borderless information technology. Related to this, the government tries to improve the quality and quantity for the sake of education. One of the efforts done by the government is usually a constitutional effort to design a globally competitive student. However, coronavirus disease 2019 (COVID-19) makes a big impact in many sectors, including education [1]. Teachers have to make sure the learning process is completed, even the teacher and students are in a separate place. As a result, the teacher should design an innovative online learning media. The provincial government and regency agree to halt the classical learning process and shift into the online learning process for elementary, middle, high school, and higher education. In higher education, the learning process is represented in a system called electronic university (e-University).
The shift in the learning process is also applied for nursing education. Nursing education is mainly aimed to master and develop nursing science in eight semesters. Ideally, the student nurse should have the ideal and skillful behavior, which is under the science he or she learns. College students are expected to be the agent of change for society. However, the shift in the learning process also affects the students' competence. Students' innovation is needed for the development of the nation, as one of the functions of college students, according to Edward Shill, is to give an impact on social change [2].

That ideal condition is different from the real condition, especially during the implementation of the online learning process, which requires students to be more independent. The teaching and learning process during the COVID-19 have the bigger chance to deal with more stressors such as the academic assignments (test and task), the difficulty in adapting with the home environment, the absence of a face-to-face meeting, and the different expectation about the nursing profession, the difficulty to adapt with the place of practice, the lack of spare time, the nervousness about mistake during the intervention, and the nervousness to meet the patients. Stress is formed when internal 
and external sources stimulate a condition which more than the adaptive capacity of a person or, in this case, a nurse student [3]. It could also happen when the student could not apply the coping strategy. Stress may lead to student nurse's behavior change such as the decrease of learning activity and enthusiasm, absence or late for the school, tend to express a cynical view on others, anger, shame, disappointment, frustration, and the loss of responsibility [4]. If the stress cannot help well coped, it may lead to a condition called burnout. This term is firstly used in the working context. However, it develops that burnout is experienced by not only workers but also students. According school or academy is a place where students work. Although students do not technically work, from the psychological perspective, their activities at school could be categorized as work, such as attending the class and doing the given assignment to pass the examination and graduate.

Burnout syndrome is a condition where the person feels exhausted and frustrated with the unachieved expectation. Burnout syndrome does not stimulate by a single factor but an interaction of some factors, such as the excessive workload [5]. It appears as the representation of increasing emotional fatigue, depersonalization, and the decrease of selfachievement (Pouncet, 2007 in Nursalam, 2016).

Among nursing understudies, burnout, which is identified with scholarly execution, can cultivate high drop-out rates and impact future nature of care in medical caretakers' expert lives. Undertaking a nursing course prompts an expanded degree of stress, burnout, and mental horribleness, which are generally identified with singular character and adapting attributes. The literature identifies three fundamental gatherings of stress causes: Academic sources of stress, clinical sources of stress, and individual/social of stress. The qualities of burnout condition in nursing understudies are sentiments of depletion, criticism, which includes a segregated and ineffectual expert conduct, and, simultaneously, the impression of themselves as an uncouth individual. However today, the exploration identified with burnout among nursing understudies is still limited [6]. The physiological fatigue impacts the decrease in daily activity, physical fatigue, weakness, the decrease of immunity, and the unstable vital signs [7].

Based on the explanation above, the researcher would like to analyze the coping mechanism toward burnout and fatigue of the online learning process during the COVID-19 pandemic. Understudies endured more noteworthy degrees of mental dreariness and burnout at the subsequent time wave, and this was generally clarified by the character attribute of neuroticism. Stress likewise expanded, and this was to a great extent clarified by emotion situated adapting. Tension is exceptionally common among nursing understudies even in ordinary conditions. In Israel during the coronavirus pandemic and compulsory lockdown, nursing understudies experienced another truth of monetary vulnerability, dread of disease, difficulties of separation training, and absence of individual security hardware personal protective equipment at work [8]. Effects of COVID-19 detailed that wellbeing laborers experienced undesirable feelings, for example, dread, hyper-excitement, meddling recollections and sleep deprivation, and enthusiastic fatigue [9]. Undertaking a nursing schooling prompts an expanded degree of stress, burnout, and mental grimness, and this is to a great extent identified with singular character and adapting traits [10], [11].

\section{Methods}

Design's research was descriptive correlative and cross-sectional approach. The population in this research was the students in the second semester of the undergraduate program in nursing Universitas Muhammadiyah Semarang. The sample of the research was 83 respondents, which were taken using a purposive sampling technique. The research was conducted by distributing an online questionnaire through Google Form about burnout, coping mechanisms, and fatigue after 3-month online learning (June 2020). The burnout questionnaire as the instrument was adapted from Budiman (2016) [12], the coping mechanism was adapted from Khasanah (2014) [13], while the questionnaire about fatigue was adapted from fatigue assessment scale. The instruments used had passed the validity and reliability test. The data were analyzed using univariate and bivariate analysis of KolmogorovSmirnoff's data normality and Pearson's productmoment statistical test.

\section{Results}

Table 1 displays age, gender, and staying place of nursing students. The sample is representative of second semester undergraduate nursing students. It showed characteristic current findings 19 years old $(59.03 \%)$, female $(92.77 \%)$, and staying at home (71.08\%).

Table 2 displays minimum, maximum, and mean nursing students fatigue, burnout, and coping. The highest mean is burnout (35.50\%).

Table 3 displays distribution frequency nursing students of coping, burnout and fatigue. The data showed current finding positive coping (56\%), severe burnout (85.5\%), and mild fatigue among students (51.8\%).

Table 4 displays correlation between coping and burnout, coping, and fatigue. The Pearson was 
Table 1: Respondents' characteristic based on age, gender, and staying place $(n=83)$

\begin{tabular}{lll}
\hline Characteristics & F & $\%$ \\
\hline Age & 1 & \\
17 & 26 & 1.20 \\
18 & 49 & 31.3 \\
19 & 3 & 59.03 \\
20 & 3 & 3.61 \\
21 & 1 & 3.61 \\
22 & 6 & 1.20 \\
Gender & 77 & 7.22 \\
Male & & 92.77 \\
Female & 59 & 71.08 \\
Staying Place & 18 & 21.68 \\
Home & 6 & 7.23 \\
$\quad$ Boarding house & & \\
Dormitory & &
\end{tabular}

used to investigate association. The data showed that there was no correlation between coping mechanism with burnout $(p=0.29)$, but there was a correlation between coping mechanism with fatigue $(p=0.00)$.

Table 2: Minimum, maximum, mean and standard deviation of fatigue, burnout, and coping $(n=83)$

\begin{tabular}{llllll}
\hline Variable & $\mathrm{n}$ & Minimum & Maximum & Mean & Standard Deviation \\
\hline Fatigue & 83 & 9.00 & 56.00 & 33.78 & 10.67 \\
Burnout & 83 & 13.00 & 56.00 & 35.50 & 8.9 \\
Coping & 83 & 19.00 & 32.00 & 26.40 & 3.10 \\
\hline
\end{tabular}

\section{Discussion}

The first aim study was to identify nursing students coping ability. The mean of students' coping ability score was 24.40 , with a standard deviation of 3.10. Most of the nurse's coping mechanism was positive coping with 47 respondents $(56.6 \%)$, and the

Table 3: Descriptive frequency of respondents based on coping, burnout, and fatigue $(n=83)$

\begin{tabular}{|c|c|c|}
\hline Variable & $F$ & $\%$ \\
\hline \multicolumn{3}{|l|}{ Coping } \\
\hline Positive & 47 & 56.6 \\
\hline Negative & 36 & 43.4 \\
\hline \multicolumn{3}{|l|}{ Burnout } \\
\hline Mild & 12 & 14.5 \\
\hline Severe & 71 & 85.5 \\
\hline \multicolumn{3}{|l|}{ Fatigue } \\
\hline Mild & 43 & 51.8 \\
\hline Severe & 40 & 48.2 \\
\hline
\end{tabular}

rest 36 respondents $(43.3 \%)$ showed negative coping mechanism. The score showed that the students were able to implement or adapt to the coping strategy well. The implementation of coping strategy represented the similarity in the students' selves, as they coped with their problem by using an adaptive coping strategy. A

Table 4: The correlation between coping mechanism, with burnout and fatigue in respondents $(n=83)$

\begin{tabular}{lll}
\hline Variable & Coping & Burnout/Fatigue \\
\hline Coping & 1000 & -0.118 \\
$\quad$ Correlation coefficient & - & 0.290 \\
$\quad$ Sig. (2-tailed) & 83 & 83 \\
$\quad \mathrm{n}$ & & \\
Burnout & -0.118 & 1000 \\
$\quad$ Correlation coefficient & 0.290 & $\cdot$ \\
$\quad$ Sig. (2-tailed) & 1000 & 0.391 \\
Fatigue & 0.00 & 0.00 \\
$\quad$ Correlation coefficient & 83 & 83 \\
$\quad$ Sig. (2-tailed) & & \\
$\mathrm{n}$ & & \\
\hline
\end{tabular}

coping mechanism is one of the aspects directed for stress management, including the effort to directly cope with problems and self-defense mechanism to protect themselves [14].

The result of the analysis showed that most of the students implemented adaptive coping as most of the students' age was 19 years old (early adult hood) considered to be almost mentally mature. It happened because students have problem solving skills, good time management, and social support. The effectiveness of a coping strategy is influenced by the type of problem at hand, but there are a number of ways that you can solve the problem efficiently, including think positively by seeing a problem as an opportunity to gain experience and learn, avoid overreacting to stress the first time you experience it, understand that no one is perfect and that everyone makes mistakes, recognize and understand precisely what problems you are experiencing by ignoring the feelings of stress they cause, try communicating the problem well with the person concerned and establish good relationships with other people-social support is very necessary in helping you to solve problems or achieve goals.

It was supported by research from Septyan (2015) that all of the respondents' age was categorized as mature, the age of which they deal with tolerance to cope with stress, and any kind of the most disturbing stressors. Young adult is a period of which challenges, achievements, and crisis would often be found.

The second aim study was identified nursing students coping. This research also found that the mean of student nurse's burnout was 35.5, with standard deviation at 8.9. Most of the burnout experienced by student nurses was severe burnout, with 71 respondents (85.5\%) and mild burnout with 12 respondents (14.5\%). The result above represented that the students' burnout was categorized as severe or poor burnout.

The COVID-19 pandemic has prompted extraordinary changes over the globe testing each part of what was recently viewed "of course" or "ordinary" life. Regular parts of past life as we were already aware it has changed and affected our own lives, work, instruction, network associations, and social exercises. For some individuals, the effect of these progressions in past pandemics has brought about mental pain [9]. The burnout experienced by student nurses usually comes to the surface as the students had experienced prolonged stress. It is contributed by the big responsibility own by a nurse. The professional tasks of nurses may lead to stressful conditions. Incomplete and slow stress management may lead to burnout in nurse students [15].

In general, burnout could decrease an ability called "concern for the task" and get information for task completion. Burnout in nurse students can at least result in vapidity, flatness, incompatibility, or unresponsiveness. Burnout could weaken the passion for obeying the commitment to keep a promise or agreement. 
Adopted the burnout syndrome theory from Maslach, burnout syndrome is an undenied situation. The particular stressors of education and training lead to strain comparable to years of expert experience and exposure to stressors [16]. However, the severity of burnout syndrome could be decreased either personally or by changing the application within the organization in which tasks should be done. In organization level, the prevention for burnout could be done by defining clear task statement, beginner participation on orientation program and job training, efficient personal planning related to the department, regulate team gathering which involves suggestion and critic delivery session, and access to participative social and society support.

The third aim study was identified nursing students fatigue. Based on the research finding, the mean of student nurses' fatigue score was 33.78, with a standard deviation of 10.6. The severe fatigue was found in 40 respondents $(48.2 \%)$; meanwhile, the rest 43 respondents $(52.8 \%)$ experienced mild fatigue. The score showed the mild fatigue of the overall students.

The fatigue in students during the online learning process is caused by the given assignment, the absence of a face-to-face meeting, the adaptation process with the home environment. Parents think when students are at home it means holidays. A lot of household chores are done by students. They commonly went through 3 months without any activities, which may lead to mild fatigue.

The fourth aim study was investigate association between coping and burnout. Based on Pearson's correlation test, it was gained that $r$ count was -0.118 with significance $(p=0.29)$. The statistical test showed the p-value bigger than 0.005 $(0.29>0.05)$. It could be concluded that the calculation resulted in an insignificant calculation. It means that there was no correlation between coping mechanisms with burnout. It implies that there was no relationship between ways of dealing with stress with burnout. It was not in accordance with the exploration directed by Nugroho (2012) that there is a relationship between adapting techniques for stress with attendant's burnout. Adapting for pressure could assist attendants with adapting to burnout. The usage powerful of adapting methodology, which is appropriate for the experienced issue, could limit burnout around attendants [17]. The result of research is different from previous research and studies because students feel severe burnout because of the large number of tasks given during online learning, besides that the subject also feels burdened with domestic assignments while at home. Lack of time management and make students have less time to work on assignments. Students choose to be quiet and rest when performance decreases.

The research finding was also not in accordance with Savitri's research (2012), which showed that emotion-focused coping could significantly decrease burnout tendency in nurse students. Meanwhile, Retno (2013) showed that there was a significant correlation between self-efficacy coping strategies with nurses' burnout levels at Rumah Sakit Jiwa Surakarta. A nurse is a profession with a high risk of burnout as the assignment of a nurse mainly deals with a responsibility to human life [15]. The responsibility sometimes transforms into a workload for a nurse. Therefore, a nurse should be able to cope or adapt to the problem so that he or she could professionally administer his or her nursing profession [14]. The higher the coping mechanism owned by a nurse, the lower risk of burnout he or she might experience [17].

The fifth aim study was to investigate association between coping and fatigue. Based on Pearson's correlation test, the $p$-value found was $<0.05$ $(0.00<0.05)$ so that the calculation was significant. It means that there is a correlation between coping mechanisms and fatigue. It is in line with research by Michalec et al., which stated [18] that there is a significant correlation between coping mechanisms and fatigue. More grounded flexibility and utilization of humor were related with altogether lower uneasiness levels, while mental separation with higher nervousness levels. The nursing office's staff may contribute in bringing down understudy uneasiness by keeping up a stable instructive structure, giving top notch far off educating, and empowering and supporting understudies through this difficult period [8].

Limitation of the current study was the low response rate which potentially limits the generalizability of the findings. Furthermore, it is possible that the study was healthy nursing students. More healthy nursing students are more productive [19]. Those were indicated low coping, low fatigue being difficulty adaptation during online learning.

\section{Conclusion}

This study documents had a positive coping mechanism, severe burnout, and mild fatigue. Coping mechanism is correlated with students' fatigue. It demonstrates a strong association between coping mechanism and students fatigue among nurse student. There is no correlation between coping mechanism and burnout. Related to this, an academic advisor should be able to give counseling and give solutions to students' problems. The ability could be improved through training or workshop. Meanwhile, for other researchers, it is hoped that this research could be continued and further developed with different methods and variables such as gender, age, and length of study. Further research could also follow the development of students with burnout and fatigue. 


\section{Acknowledgment}

We would like appreciate to all students who participated in this research and Bachelor of Nurse Program University of Muhammadiyah Semarang specialized second semester, Head of Nurse Program University of Muhammadiyah Semarang and Dean of Faculty of Nursing and Health Sciences.

\section{References}

1. Dos Santos LM. The relationship between the COVID-19 pandemic and nursing students' sense of belonging: The experiences and nursing education management of preservice nursing professionals. Int J Environ Res Public Health. 2020;17(16):5848. https://doi.org/10.3390/ijerph17165848 PMid:32806697

2. Skodova $Z$, Lajciakova $P$. The effect of personality traits and psychosocial training on burnout syndrome among healthcare students. Nurse Educ Today. 2013;33(11):1311-5. https://doi. org/10.1016/j.nedt.2013.02.023

PMid:23545453

3. Nurhidayati T. Stress level of apprenticeship nursing student UNIMUS at Community stage. Fikkes.2014;(1):1-8.

4. Deary IJ, Watson R, Hogston R. A longitudinal cohort study of burnoutandattritioninnursingstudents. JAdvNurs. 2003;43(1):7181. https://doi.org/10.1046/j.1365-2648.2003.02674.x PMid:12801398

5. Valero-Chillerón MJ, González-Chordá VM, López-Peña N, Cervera-Gasch Á, Suárez- MP, Mena-Tudela D. Burnout syndrome in nursing students: An observational study. Nurse Educ Today. 2019;76:38-43. https://doi.org/10.1016/j.nedt.2019.01.014 PMid:30769176

6. Portuguesa C. Projeto BioMar PT. Empathy and burnout: An analytic cross-sectional study among. Acta Biomed for Health Professions 2016;86(1):104-115.

7. Eaves JL, Payne N. Resilience, stress and burnout in student midwives. Nurse Educ Today. 2019;79:188-93. https://doi. org/10.1016/j.nedt.2019.05.012 PMid:31153089

8. Savitsky B, Findling Y, Ereli A, Hendel T. Anxiety and coping strategies among nursing students during the COVID-19 pandemic. Nurse Educ Pract. 2020;46:102809. https://doi. org/10.1016/j.nepr.2020.102809

\section{PMid:32679465}

9. Usher K, Bhullar N, Wynaden D, Durkin J, Jackson D. The mental health impact of COVID-19 on pre-registration nursing students in Australia. Int J Ment Health Nurs. 2020;29(6):10157. https://doi.org/10.1111/inm.12791 PMid:32885572

10. Watson R, Deary I, Thompson D, Li G. A study of stress and burnout in nursing students in Hong Kong: A questionnaire survey. Int J Nurs Stud. 2008;45(10):1534-42. https://doi. org/10.1016/j.jinurstu.2007.11.003

PMid: 18241870

11. Almojali Al, Almalki SA, Alothman AS, Masuadi EM, Alaqeel K. The prevalence and association of stress with sleep quality among medical students. J Epidemiol Glob Health. 2017;7(3):169-74. https://doi.org/10.1016/j.jegh.2017.04.005 PMid:28756825

12. Arlinkasari F, Akmal SZ. School Engagement, Academic Selfefficacy and Academic Burnout's college students. 2017;1(2):81. https://doi.org/10.28932/humanitas.v1i2.418

13. Khasanah ML, Wuryanto.E, Nurhidayati T. Analisis Mekanisme Koping Mahasiswa Semester I Menghadapi Ujian Mahasiswa Program Studi S1 Keperawatan Fikkes Unimus, Prosiding Konferensi Nasional; 2014. https://doi.org/10.32528/psn. v0i0.1728

14. Ratri MS, Parmitasari DL. Coping stress pada beban kerja perawat ruang unit pelayanan intensive psikiatri (Upip) dan ruang kresna Di Rsjd Dr. Amino Gondohutomo Semarang. Psikodimensia. 2014;13:1-17. Available from: http://www. journal.unika.ac.id/index.php/psi/article/view/266.

15. Makassar RH, Haji R, Makassar M, Kunci K. Relation of Education, Years of Work and Workload on Patient Safety of Haji Makassar Hospital Astriana, Noer Bahry Noor, Andi Indahwaty Sidin Rumah Sakit Merupakan Layanan Jasa Yang Memiliki Peran Penting Dalam Kehidupan Masyarakat, Rumah Sakit Merupa; 2014. p. 1-8. https://doi.org/10.30597/jkmm.v1i2.8714

16. Hausmann C. Burnout symptoms in Austrian student nurses in their third year of training. Pflege. 2009;22(4):297-307. PMid:19650035

17. Nugroho AS, Andrian, Marselius. Studi deskriptif burnout dan coping stres pada perawat di ruang rawat inap Rumah Sakit Jiwa Menur Surabaya. Calyptra. 2012;1(1):1-6. https://doi. org/10.35913/jk.v4i2.70

18. Michalec B, Diefenbeck C, Mahoney M. The calm before the storm? Burnout and compassion fatigue among undergraduate nursing students. Nurse Educ Today. 2013;33(4):314-20. https:// doi.org/10.1016/j.nedt.2013.01.026 PMid:23434192

19. Patrick K, Lavery JF. Burnout in nursing. Aust J Adv Nurs. 2007;24(3):43-8.

PMid: 17518165 